\title{
Use of Quantitative Molecular Diagnostic Assays to Investigate Fusarium Dry Rot in Potato Stocks and Soil
}

\author{
D. W. Cullen, I. K. Toth, Y. Pitkin, N. Boonham, K. Walsh, I. Barker, and A. K. Lees
}

First, second, third, and seventh authors: Scottish Crop Research Institute, Invergowrie, Dundee, Scotland, DD2 5DA, UK; and fourth, fifth, and sixth authors: Central Science Laboratory, DEFRA, Sand Hutton, York, YO41 1LZ, England, UK.

Accepted for publication 27 July 2005.

\begin{abstract}
Cullen, D. W., Toth, I. K., Pitkin, Y., Boonham, N., Walsh, K., Barker, I., and Lees, A. K. 2005. Use of quantitative molecular diagnostic assays to investigate Fusarium dry rot in potato stocks and soil. Phytopathology $95: 1462-1471$

Specific and sensitive quantitative diagnostics, based on real-time (TaqMan) polymerase chain reaction (PCR) and PCR enzyme-linked immunosorbent assay, were developed to detect dry-rot-causing Fusarium spp. ( $F$. avenaceum, F. coeruleum, F. culmorum, and $F$. sulphureum). Each assay detected Fusarium spp. on potato seed stocks with equal efficiency. Four potato stocks, sampled over two seed generations from Scottish stores, were contaminated with $F$. avenaceum, $F$. sulphureum, $F$. culmorum, $F$. coeruleum or a combination of species, and there was a general trend towards increased Fusarium spp. contamination in the second generation of seed sampled. $F$. sulphureum and $F$. coeruleum

$10^{6}$ conidia/ml). Increased DNA levels were correlated with increased disease severity between 8 and 12 weeks of storage. The threshold inoculum levels resulting in significant disease development on both cultivars were estimated to be $10^{4}$ conidia/ml for F. sulphureum and $10^{5}$ conidia $/ \mathrm{ml}$ for $F$. coeruleum. To study the effect of soil infestation and harvest date on disease incidence, seed tubers of cvs. Morene and Spunta were planted in a field plot artificially infested with the four Fusarium spp. F. culmorum and F. sulphureum were detected in soil taken from these plots at harvest, and $F$. sulphureum DNA levels increased significantly $(P<0.05)$ at the final harvest. All four Fusarium spp. were detected in progeny tubers. There was a trend toward higher levels of $F$. culmorum detected in progeny tubers at the earliest harvest date, and higher levels of $F$. sulphureum at the final harvest. The use of diagnostic assays to detect fungal storage rot pathogens and implications for disease control strategies are discussed.
\end{abstract} caused significantly $(P<0.05)$ more disease in storage than the other species when disease-free tubers of potato cvs. Spunta and Morene were inoculated at a range of inoculum concentrations $\left(0,10^{4}, 10^{5}\right.$, and
Additional keyword: pathogenicity.
Dry rot is an important storage disease of potato tubers (Solanum tuberosum L.) that can be caused by several Fusarium spp. and is of economic significance worldwide (31). Recent reports showed that $70 \%$ of ware crops and $100 \%$ of seed stocks were affected by the disease in southeast England, with as many as $1 \%$ of tubers showing disease symptoms (5). In addition, Carnegie et al. (8) reported that $60 \%$ of graded tubers can be affected by dry rot fungi during storage, and annual crop losses attributed to dry rot have been estimated to average from 6 to $25 \%$ (9). Fungal infection of tubers occurs mainly through wounds and inoculum is spread during planting, mechanical harvesting, and grading. Symptoms of dry rot on tubers appear as dark, sunken, and wrinkled patches producing white, pink, or blue pustules, and infection can lead to seed tuber rot (31). All commercially grown potato cultivars are considered susceptible to the disease $(19,38)$.

Thirteen species of Fusarium have been implicated in causing dry rot worldwide. F. sulphureum Schlechtend. (syn. F. sambucinum Fuckel) is the most common pathogenic species in North America and regions of Europe $(15,16,21,31,37)$, whereas F. coeruleum (Libert) Sacc. (syn. F. solani var. coeruleum) is considered to be the predominant causal agent in the United Kingdom $(16,24)$. Other pathogenic species associated with dry rot, and usually considered to be of lesser importance, include F. avenaceum (Fr.:Fr.) Sacc., F. culmorum (Wm. G. Sm.) Sacc., F. oxysporum Schlechtend.:Fr., F. acuminatum Ellis \& Everh.,

Corresponding author: A. K. Lees; E-mail address: alees@ @cri.sari.ac.uk

DOI: 10.1094/PHYTO-95-1462

(C) 2005 The American Phytopathological Society
F. crookwellense L. W. Burgess, P. E. Nelson \& T. A. Toussoun, F. equiseti (Corda) Sacc., F. graminearum Schwabe, F. scirpi Lambotte \& Fautrey, F. semitectum Berk. \& Ravenel, F. sporotrichioides Sherb., and F. tricintum (Corda) Sacc. (14,16,29-32). The differences in pathogenicity and distribution of this diverse group of Fusarium spp. highlight the necessity for the development of diagnostics for the rapid and accurate identification of such species to facilitate management and control strategies for dry rot.

Contaminated seed or rotting tubers are significant sources of inoculum for the transmission of Fusarium spp. (4), and diseased seed results in soil infestation $(1,10,18)$. There is little information about the epidemiology of dry-rot-causing Fusarium spp. Several studies demonstrated that transmission of $F$. sulphureum to progeny tubers was greater from highly contaminated seed than from rotting seed. This is in contrast to the observations for $F$. coeruleum, which appeared to be transmitted most readily from the rotted mother tuber $(1,6,10)$. These differences in transmission were attributed to the different capacity of each pathogen to sporulate underground on seed tubers and on stem bases: F. coeruleum sporulates on the outside of rotting seed tubers, whereas $F$. sulphureum rarely does so, but sporulates more readily on stem bases $(1,10)$.

The seed tuber is the main source of inoculum; therefore, dry rot control strategies have incorporated the use of fungicide seed treatments. Control of dry rot on stored tubers was achieved in the 1970 s and most of the 1980s by postharvest application of the benzimidazole fungicide, thiabendazole (TBZ). However, resistance to TBZ is now widespread among North American and European Fusarium spp., including F. sulphureum $(13,15,16,34)$, 
F. coeruleum (15), F. avenaceum (26), F. culmorum $(15,16)$, $F$. oxysporum, and $F$. acuminatum (15), and this has resulted in an increased incidence and severity of dry rot (28). Alternative fungicides such as imidazole compounds and mixtures containing TBZ were tested, with some success, for controlling dry rot $(7,8)$. Other control and management strategies, including the application of organic and inorganic salts (21), ultraviolet radiation (25), biological control (27), and cultural practices such as crop rotation, use of disease-free seed, reduction of wounds during harvesting, and wound healing of stored potato tubers (28), have been recommended. However, in order to validate such recommendations and ensure disease-free stocks, the potato industry requires robust and reliable diagnostics for the detection of the predominant dry-rot-causing Fusarium spp. Such diagnostics would provide a rapid means of identifying and quantifying pathogen inoculum levels in diseased stocks and in soil and, thus, provide more accurate information on which to base management decisions.

In recent years, polymerase chain reaction (PCR) has emerged as a useful tool for the detection and identification of fungal pathogens. This study focused on the development of two different quantitative PCR diagnostic systems; real-time (TaqMan) PCR and microtiter plate-based (MTP) PCR enzyme-linked immunosorbent assay (ELISA). The real-time PCR technique has been developed to enable the quantification of nucleic acids in unknown samples by a direct comparison to standards amplified in parallel reactions. Conventional PCR assays can be adapted to MTP-based PCR-ELISA systems based on the detection of digoxigenin (DIG)-labeled PCR products (Roche UK Ltd.), and this system also can be adapted for quantitative PCR applications using an internal competitor standard as for competitive PCR. The main advantage of using a PCR-ELISA system compared with real-time PCR technology is the cost of purchasing equipment. Both systems were developed in order to provide both a sensitive tool for epidemiological investigations and to facilitate in-house testing by industry.

The objectives of the research were to (i) confirm the predominant Fusarium spp. responsible for dry rot in the United Kingdom, (ii) use specific DNA sequences from these species to develop quantitative PCR assays, and (iii) use these assays to investigate the extent of dry rot in potato stocks, the factors affecting disease development during storage, and the relationship between inoculum load and disease risk.

\section{MATERIALS AND METHODS}

Extraction of DNA from pure cultures, soils, and potato tubers. Pure cultures. Fungal cultures were grown on potato dextrose agar (PDA) (Difco, West Molesey, UK) at $18^{\circ} \mathrm{C}$, and DNA was extracted according to the method of Nicholson et al. (22), except that cell lysis was performed using a Mini-BeadBeater-8 (Bio-Spec Products, Bartlesville, OK) set at a medium setting/1 min.

Tuber and soil samples. DNA was extracted from tuber peel sap and soil suspensions by physical disruption in a MiniBeadBeater- 8 using the method described by Cullen et al. (11).

Pathogenicity assays. Conidial suspensions were prepared in sterile $\mathrm{dH}_{2} \mathrm{O}$ by scraping conidia from the surface of cultures grown on PDA for 21 days at $18^{\circ} \mathrm{C}$. Conidial concentration (conidia $\mathrm{ml}^{-1}$ ) was determined using a hemacytometer and dilutions were made in sterile $\mathrm{dH}_{2} \mathrm{O}$ to give the required concentrations for inoculation. Seed potato tubers of cvs. Spunta and Morene ranging in size from 80 to $100 \mathrm{~mm}$ were inoculated individually with four inoculum concentrations $\left(0,10^{4}, 10^{5}\right.$, or $10^{6}$ conidia $\left.\mathrm{ml}^{-1}\right)$ of one isolate each of $F$. avenaceum (37T1), F. culmorum (41T4), $F$. coeruleum (42T2), and $F$. sulphureum (14T1b). These four isolates of Fusarium spp. were isolated from potato in 2000 and their pathogenicity on potato (cv. Cara) was confirmed.
Tubers (five per treatment per date, two replicates) were wounded with a sterile scalpel around the circumference from the rose to heel end, immersed for $10 \mathrm{~s}$ in either a conidial suspension or $\mathrm{dH}_{2} \mathrm{O}$ as a control, transferred to trays, air dried overnight, and incubated in a controlled growth cabinet set at $12^{\circ} \mathrm{C}$ and $85 \%$ relative humidity. Tubers were examined for disease at three time points $(2,8$, and 12 weeks of incubation) and scored as follows: $0=$ no infection and $1=0$ to $12.5,2=12.5$ to $25,3=25$ to 50 , $4=50$ to 75 , and $5=>75 \%$ surface area of tuber diseased. Tubers also were tested by real-time PCR at each time point to determine the actual level of Fusarium spp. contamination resulting from the artificial inoculations over time. Five tubers were removed from each tray per sampling date and scored for disease and the DNA was extracted as described above.

Sampling potato stocks for presence of Fusarium spp. Tubers of three potato cultivars (Morene, Hermes, and Spunta) with differing resistance to dry rot were sampled from stocks stored in one commercial seed store but originating from different fields; Morene was considered to be the most resistant cultivar and Spunta the least resistant from commercial knowledge. Firstfield-generation stocks (named A, C, F, and G) were sampled in December 2000 (date 1) and February 2001 (date 2), and again as the second generation, in December 2001 (date 3) and February 2002 (date 4). Stocks were monitored by randomly sampling $10 \%$ of the total number of 1-tonne boxes per stock; thus, a total of 10 (A), $20(\mathrm{C}), 14(\mathrm{~F})$, and $20(\mathrm{G})$ boxes were sampled according to a plan devised by Biomathematics \& Statistics Scotland (BioSS). Twelve tubers, randomly sampled from all areas within each box, were peeled, the peel sap collected and pooled, and the DNA extracted from each pooled extract as previously described. Individual DNA extracts from each box in a stock were subsequently tested for all four dry-rot-causing Fusarium spp. using real-time PCR. Stocks C (Morene) and F (Spunta) were chosen to make a comparison of the real-time PCR and PCR-ELISA assays due to the difference in host resistance to dry rot.

Effect of soil contamination and harvest date on disease incidence. A field site containing a sandy loam soil type was inoculated with a combined conidial/mycelial inoculum of all four Fusarium spp. to provide an infested site for trials. Fusarium isolates were grown on PDA for 14 days at $18^{\circ} \mathrm{C}$, and cultures of each species were then resuspended in $1,500 \mathrm{ml}$ of $\mathrm{dH}_{2} \mathrm{O}$ and homogenized in a blender to produce an inoculum suspension. A 10 -fold dilution series of this suspension was prepared in sterile $\mathrm{dH}_{2} \mathrm{O}$ and $0.1-\mathrm{ml}$ aliquots were spread onto five replicate PDA plates to determine the number of $\mathrm{CFU} / \mathrm{ml}$. Plate counts recorded for $F$. avenaceum, $F$. coeruleum, $F$. culmorum, and $F$. sulphureum were $13.6 \times 10^{6}, 4.0 \times 10^{5}, 1.3 \times 10^{5}$, and $6.6 \times 10^{5} \mathrm{CFU} / \mathrm{ml}$, respectively.

The four fungal suspensions were combined in a bucket and mixed thoroughly with $6 \mathrm{~kg}$ of vermiculite, and this suspension was spread evenly along each drill and mixed into the soil surface at the field site. Two replicate soil samples $(50 \mathrm{~g})$ were collected from each plot before and after the addition of the inoculum. Seed tubers of Morene and Spunta were planted on 22 May 2002 at the infested field site in a randomized complete block design consisting of five tubers per plot in three replicates for each harvest date. Six drills (8.4 m long) were planted and each section was separated by a $1.2-\mathrm{m}$ path and surrounded by unused drills or $1.2-\mathrm{m}$ paths. Plots were left to senesce naturally, and tubers were harvested by fork and collected in paper bags on three occasions: 4 September, 17 September, and 5 November 2002. Daughter tubers were inspected for disease, and 10 random tubers per replicate were PCR tested for the presence of Fusarium spp. Two replicate soil samples also were collected at each harvest within the plant zone at tuber depth for each plot and DNA was extracted from duplicate subsamples.

Design of PCR primers and probes to detect dry-rot-causing Fusarium spp. The internal transcribed spacer (ITS) regions 
(ITS1 and ITS2) of the rDNA gene of six isolates each of $F$. coeruleum and $F$. sulphureum, and four isolates each of $F$. avenaceum and F. culmorum, all isolated in 2000 from diseased potato of UK stocks, were amplified with the universal primers ITS5/ITS4 (40). PCR products were purified and sequenced on two separate occasions according to the methods of Cullen et al. (11). ITS1 and 2 and 5.8S rDNA regions were subjected to a database search using both the BLAST and FASTA programs, and these sequences were aligned using the Clustal V package (17) to the same regions of 40 different species of Fusarium in order to identify speciesspecific sequences.

Regions of dissimilarity were used to design primers for the specific detection of $F$. coeruleum and $F$. sulphureum (Table 1). The annealing temperatures of these primers were standardized to ensure operation under standard PCR conditions. There was insufficient interspecific or intergeneric sequence heterogeneity among the ITS sequences of $F$. avenaceum and $F$. culmorum to design specific primers for conventional PCR. Therefore, the published primer sequences based on random amplified polymorphic DNA fragments (Table 1) for the specific detection of $F$. avenaceum (35) and F. culmorum (22) in cereals were tested under the standard PCR conditions for detection of these species from potato.
Biotin-labeled capture probes also were designed within regions of each PCR product amplified for each Fusarium sp. for use in the PCR ELISA assay described below (Table 1).

Conventional PCR used for ELISA. Standard PCR amplification of all genomic, peel, and soil extract DNA samples and analysis was performed by the methods according to Cullen et al. (11), except that an annealing temperature of 65 instead of $60^{\circ} \mathrm{C}$ was used for F. culmorum to ensure specificity. PCR primers and capture probes designed for the specific detection of potato dry rot pathogens by conventional PCR and PCR-ELISA are listed in Table 1.

Adaptation of conventional PCR assays to MTP-PCRELISA. The MTP system developed for the detection of dry rot pathogens was based on the detection of DIG-labeled PCR products (Roche UK Ltd.). Each assay was adapted for quantitative PCR using a unique internal competitor standard, with the same primer binding sites as the specific target DNA for all four species of Fusarium but with a different internal sequence for the design of a single competitor-specific capture probe. A segment of the nptII gene of Tn5 (3) cloned into a plasmid vector (pGEM-T; Promega, Southampton, UK) was used to produce a fragment (260 bp) of unrelated DNA flanked by primer binding sites for

TABLE 1. Conventional and Taqman polymerase chain reaction (PCR) primers and probes designed for the specific detection of dry rot pathogens

\begin{tabular}{|c|c|c|c|}
\hline \multicolumn{2}{|l|}{ Primers and probes } & \multicolumn{2}{|c|}{ Product size (bp) } \\
\hline Fusarium spp., ID & Sequence $\left(5^{\prime}\right.$ to $\left.3^{\prime}\right)$ & Fusarium sp. & Competitor \\
\hline \multicolumn{4}{|c|}{ Conventional PCR primers } \\
\hline \multicolumn{4}{|c|}{ F. coeruleum } \\
\hline Fcoer2R $1^{\mathrm{a}}$ & CTGGTCCGCGAAGGACAC & & \\
\hline FcrBIOP2 $^{\mathrm{b}}$ & GGTTTGGTGTTGGGGAT & & \\
\hline \multicolumn{4}{|l|}{ F. sulphureum } \\
\hline \multicolumn{4}{|l|}{ F. avenaceum $(35)$} \\
\hline JIAf & GCTAATTCTTAACTTACTAGGGGCC & 294 & 386 \\
\hline $\mathrm{JIAr}^{\mathrm{a}}$ & CTGTAATAGGTTATTTACATGGGCG & & \\
\hline FavBIOP1 ${ }^{a}$ & ACATGTTCCGCATCGAT & & \\
\hline \multicolumn{4}{|l|}{ F. culmorum (22) } \\
\hline $\mathrm{Fc} 01 \mathrm{~F}$ & ATGGTGAACTCGTCGTGGC & 592 & 495 \\
\hline \multicolumn{4}{|l|}{ F. avenaceum } \\
\hline Aven246(F) & GCAAAATGCGATAAGTAATGTGAATT & 88 & $\ldots$ \\
\hline Aven334(R)A & GCCCGCCGGAAAAGCA & & \\
\hline AvenRC $(\mathrm{P})^{\mathrm{c}}$ & TGCGTTCAAAGATTCGATGATTCACTGAATTCTG & & \\
\hline \multicolumn{4}{|c|}{ 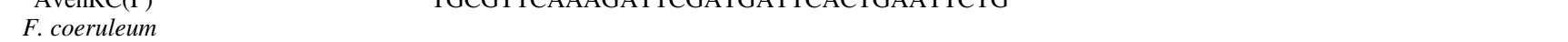 } \\
\hline Coer(F)P & GCGTAGTAGCTAACACCACGGATTC & 80 & $\ldots$ \\
\hline Coer534(R) & GATCCGAGGTCAACATTCAGAAG & & \\
\hline $\operatorname{Coer}(\mathrm{P})^{\mathrm{c}}$ & CGCGGCCATGCCGTTAAACAC & & \\
\hline \multicolumn{4}{|l|}{ F. culmorum } \\
\hline $\mathrm{Cul} 370(\mathrm{~F})$ & TTGGTGTTGGGAGCTGCA & 67 & $\ldots$ \\
\hline Cul437(R) & CTATGGAAGCTCGACGTGACC & & \\
\hline $\operatorname{Culm}(\mathrm{P})^{\mathrm{c}}$ & CCTGCTGCACTCCCCAAATACATTGG & & \\
\hline \multicolumn{4}{|l|}{ F. sulphureum $\mathrm{d}$} \\
\hline
\end{tabular}


F. coeruleum, F. sulphureum, F. avenaceum, and F. culmorum. The competitor fragment was produced by sequential PCR amplification of products using three sets of primers under standard PCR conditions to incorporate primer binding sites for each of the four Fusarium spp., as outlined in Figure 1.

The four sets of Fusarium-specific primers were tested with the final version of the competitor standard (503 bp) to verify its use for competitive PCR, and each set produced the predicted size of PCR product (Table 1), which was reliably detected on agarose gels down to attogram $\left(\mathrm{ag} ; 10^{-18} \mathrm{~g}\right)$ levels of starting template DNA. A biotin-labeled capture probe $(\mathrm{OmBP})$ also was designed within the $n p t I I$ gene sequence of the competitor standard for use in a PCR-ELISA assay (Table 1).

Various concentrations of competitor standard were tested together with Fusarium sp. DNA to determine a suitable concentration for the efficient amplification of both products and to permit the construction of a standard curve. DNA was extracted from tuber peel extracts $(0.5 \mathrm{ml})$ seeded with a dilution series of individual suspensions $\left(10^{6}, 10^{5}, 10^{4}, 10^{3}, 10^{2}, 10^{1}\right.$, and $10^{0}$ conidia/ml $)$ of macroconidia from cultures of $F$. coeruleum, $F$. sulphureum, $F$. avenaceum, and $F$. culmorum on two occasions. These DNA samples were tested by PCR in the presence of different concentrations of competitor fragment ( 5 to $50 \mathrm{ag}$ per reaction) to pro- duce a standard curve based on signals obtained from DIG detection (described below) using the target-specific probe with those obtained from the competitor-specific capture probe (target:competitor signal ratios). The same seeded peel DNA extracts also were tested by real-time PCR to produce standard curves for each specific assay and to determine the equivalent number of conidia from the quantity of target DNA (ng) detected.

PCR-ELISA (DIG detection) of dry rot pathogens. The quantitative detection of DIG-labeled PCR products was carried out following the manufacturer's instructions (catalog no. 1965 409; Roche UK Ltd.). PCR-ELISA assays were optimized and the optimum conditions for all capture probe assays were obtained using $5 \mu \mathrm{l}$ of PCR product, capture probe at 10 to $20 \mathrm{pmol} / \mathrm{ml}$ (15 $\mathrm{pmol} / \mathrm{ml}$ as standard), $2 \mathrm{~h}$ of hybridization, anti-DIG-POD at $0.1 \mathrm{U} / \mathrm{ml}$, and $1 \mathrm{~h}$ for reliable colorimetric development. Triplicate PCR reactions were performed for each sample when testing peel DNA extracts, and duplicate 5- $\mu$ l volumes of PCR product per sample were used for each specific target and competitor capture probes. The absorbance of each well (target and corresponding competitor signals) at $405 \mathrm{~nm}$ was measured using a plate reader, and the extinction of the negative controls was subtracted from the absorbance of each sample. The cut-off value was the mean value of the negative control plus three times the standard devia-

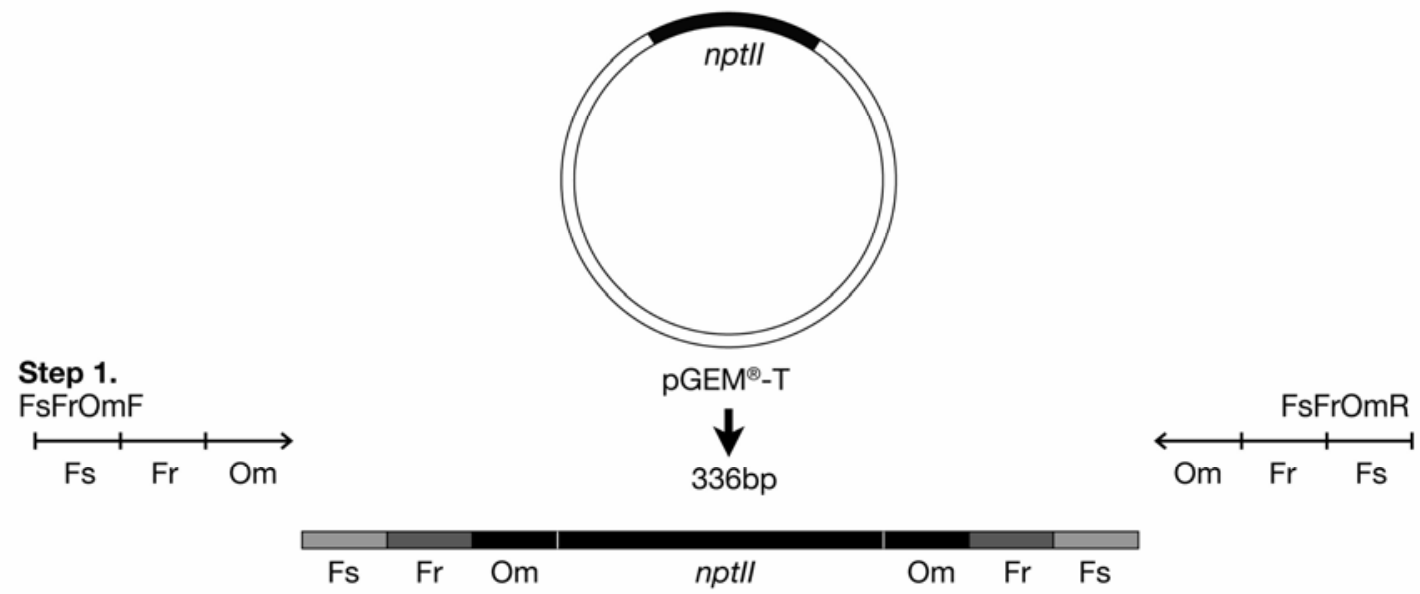

Step 2. FaFsF
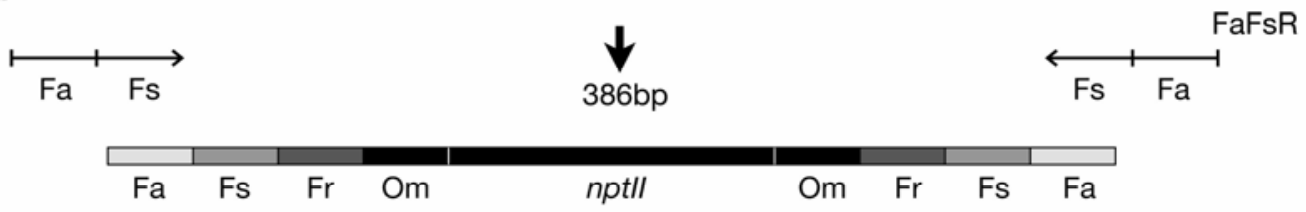

Fr Fs

Step 3.

FcOm35FaF
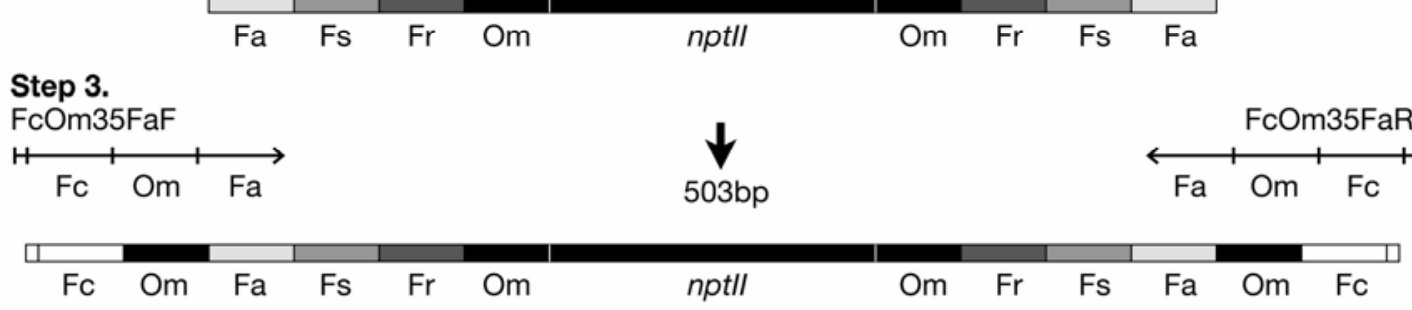

\begin{tabular}{|lll|}
\hline Key: & $\mathrm{Fr}=F$. coeruleum \\
Om $=$ nptII DNA & $\mathrm{Fs}=F$. sulphureum & $\mathrm{Fa}=F$. avenaceum \\
& $\mathrm{Fc}=F$. culmorum \\
\hline
\end{tabular}

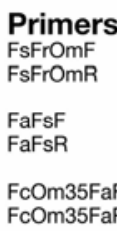

(5'-ATCAGCCCGTTCCTCGGA ACCCAAACTCTATTG TIIITAG AGACAATCGGCTGCTCTGATG-3') (5'-GGGAGTG TCAGACGACAG CTGGTCCGCGAAGGACAC TACTITCTCGGCAGGAGCAAG-3')

(5'-GCTAATTCTTAACTTACTAGGGGCC ATCAGCCCGTTCCTCGGA-3')

(5'-actg ATGGTGAACTCGTCGTGGCACATCGCATCGAGCGAGCA CGTACTCGGATGGAAG GCTAATTCTTAACTTACTAGGGGCC-3') (5'-agtaCCCTTCTTACGCCAATCTCGTTCTGGATTCATCGACT GTGGCCGGCTGGGT GTGG CTGTAATAGGTTATTIACATGGGCG-3')

Fig. 1. Flow diagram illustrating the design of a competitor fragment for polymerase chain reaction enzyme-linked immunosorbent assay. 
tion from triplicate assays. The number of Fusarium conidia/ml of peel extract for test samples was determined from the corresponding mean target:competitor DNA ratios and the linear regression equation for each standard curve.

Real-time (TaqMan) quantitative PCR. Additional sets of species-specific primers and probes were designed in the ITS regions of $F$. coeruleum, $F$. sulphureum, $F$. avenaceum, and $F$. culmorum to meet the optimal requirements for fluorescent PCR technology based on amplicons between 50 to $150 \mathrm{bp}$ in length (Applied Biosystems, Foster City, CA) (Table 1). Realtime PCR assays were optimized by performing primer and probe titrations using DNA from appropriate species.

Real-time PCR was performed in MicroAmp optical 96-well plates using the automated ABI Prism 7900 HT sequence detector (Applied Biosystems). Real-time PCR reactions involved the addition of $1 \mu \mathrm{l}$ of DNA (diluted 1/50 in molecular biology grade water) to an optimized mix consisting of TaqMan Buffer A (1x), AmpliTaq Gold DNA polymerase $(0.025 \mathrm{U} / \mu \mathrm{l}), \mathrm{MgCl}_{2}(3.5 \mathrm{mM})$, $0.2 \mathrm{mM}$ each of dNTP, $100 \mathrm{nM}$ probe for all assays, and 100 (cytochrome oxidase), 300 (F. culmorum), or $900 \mathrm{nM}$ (F. avenaceum, $F$. culmorum, and $F$. sulphureum) each for forward and reverse primers (Table 1) (Applied Biosystems), and molecular biology grade water to a final volume of $25 \mu \mathrm{l}$. An assay to detect the cytochrome oxidase (COX) gene was designed for use as a potato endogenous control during quantification using the TaqMan PCR system (39) (Table 1). Thus, this gene can be used as a normalizer assay to reflect the total amount of DNA in each extract. All tuber extract samples were tested simultaneously in duplicate for both the pathogen target DNA and COX gene DNA levels in separate wells, and each target DNA level was divided by the corresponding COX gene level in the sample to obtain normalized data.

All fluorogenic probes were labeled at the $5^{\prime}$ end with the fluorescent reporter dye 6-carboxy-fluorescein (FAM), and the $3^{\prime}$ end was modified with the quencher dye 6-carboxy-tetramethylrhodamine (TAMRA) except for the COX gene assay, in which the

TABLE 2. Fungal species used for testing the specificity of all dry-rot-causing Fusarium spp. primers and probes

\begin{tabular}{|c|c|}
\hline \multicolumn{2}{|c|}{ Fungal species } \\
\hline Alternaria brassicae ${ }^{\mathrm{a}}$ & Fusarium sporotichioides \\
\hline Botrytis cinerea & Fusarium sulphureum \\
\hline Colletotrichum coccodes & Fusarium trichothecioides \\
\hline Cylindrocarpon spp. & Fusarium tricinctum \\
\hline Erysiphe graminis f. sp. avenae & Fusarium tabacinum \\
\hline Erysiphe graminis f. sp. hordei & Helminthosporium solani \\
\hline Fusarium acuminatum & Leptosphaeria maculans ${ }^{\mathrm{a}}$ \\
\hline Fusarium avenaceum & Nectria haematococca ${ }^{\mathrm{a}}$ \\
\hline Fusarium chlamydosporum & Neurospora crassa ${ }^{\mathrm{a}}$ \\
\hline Fusarium coeruleum & Phoma exigua var. foveata \\
\hline Fusarium compartum & Phytophthora cactorum \\
\hline Fusarium concelor & Phytophthora cryptogea \\
\hline Fusarium crookwellense & Phytophthora erythroseptica \\
\hline Fusarium culmorum & Phytophthora fragariae \\
\hline Fusarium equiseti & Phytophthora infestans \\
\hline Fusarium graminearum & Polyscytalum pustulans \\
\hline Fusarium lateritium & Puccinia recondita f. sp. tritici \\
\hline Fusarium moniliforme & Pyrenopeziza brassicae $^{\mathrm{a}}$ \\
\hline Fusarium nivale & Pythium ultimum \\
\hline Fusarium oxysporum & Rhizoctonia solani \\
\hline Fusarium pallidoroseum & Sclerotinia sclerotiorum ${ }^{\mathrm{a}}$ \\
\hline Fusarium poae & Spongospora subterranean \\
\hline Fusarium proliferatum & Tapesia yallundae ${ }^{\mathrm{a}}$ \\
\hline Fusarium semitectum & Verticillium dahliae ${ }^{\mathrm{a}}$ \\
\hline $\begin{array}{l}\text { Fusarium solani var. coeruleum } \\
\text { Fusarium solani }\end{array}$ & Verticillium lecanu \\
\hline
\end{tabular}

a DNA samples were obtained from S. Foster, Rothamsted Research, Harpenden, UK. Remaining DNA samples were extracted from cultures obtained from reference collections at SCRI or from the Central Science Laboratories, York, UK. probe was labeled at the $5^{\prime}$ end with the reporter VIC (Applied Biosystems). The recommended generic (three-stage) thermal cycle protocol was used for PCR amplification (Applied Biosystems). All quantities of target DNA were measured using a standard curve constructed by plotting critical threshold $(\mathrm{Ct})$ values versus the log of the initial concentration of Fusarium spp. DNA standards (cloned PCR products) present. The $\mathrm{Ct}$ values for each PCR reaction were extrapolated from the standard curves to calculate the amount of Fusarium spp. target DNA in a sample, with adjustments being made for the total amount of potato DNA present as determined by the COX gene assay. The number of Fusarium conidia per milliliter of peel extract for test samples was determined from mean DNA values per stock and the linear regression equation for each standard curve.

Statistical analyses. Statistical analysis of the data was performed using the Genstat for Windows program 6.0. All comparisons were made by analysis of variance (ANOVA) tests performed by general linear models (GLM) with a binomial distribution error term and logit link function, and the data was recoded; zero values $=0$, and non-zero values $(>0)=1$. Differences were considered significant at $P \leq 0.05$.

\section{RESULTS}

Specificity and sensitivity of PCR, PCR-ELISA, and TaqMan assays. DNA was extracted from 435 cultures of plant pathogens from reference collections held at SCRI and CSL, and 80 isolates recently obtained from potato, in order to test the specificity of all PCR assays. Primers for the detection of $F$. coeruleum (Fcoer1F1/Fcoer2R1; $271 \mathrm{bp}$ ) and $F$. sulphureum (Fsulp1F1/Fsulp2R1; 291 bp) amplified the expected size of product from all isolates of these species tested, including putative cultures recently isolated from UK potato stores in 2000. The published primer sequences for the specific detection of $F$. avenaceum (JIAf/JIAr) (35) and F. culmorum ( $\mathrm{Fc01F} / \mathrm{Fc} 01 \mathrm{R})$ (22) successfully confirmed the identity of all isolates of these species. No amplification products were generated when each primer set was tested with a range of other plant pathogens, including 25 different species of Fusarium (Table 2).

The DIG-labeled reverse primers were tested in a conventional PCR assay with the same forward primer, and the sensitivity of detection (1 to $10 \mathrm{pg}$ of DNA) by gel electrophoresis was comparable to that using the unlabeled primers for all four Fusarium spp. The use of the original forward and reverse primers ensured the same high levels of specificity as with conventional PCR and eliminated the need for further optimization and specificity tests. Indeed, the same level of specificity was achieved but with increased sensitivity (at least 10-fold) using each primer set together with an appropriate capture probe when adapted to the MTP-PCR-ELISA format. The sequence and size of PCR products amplified with each primer set was confirmed by sequencing products generated from three different isolates of each species.

It was possible to reliably detect specific signals from 50 to 100 femtograms $\left(\mathrm{fg} ; 10^{-15} \mathrm{~g}\right.$ ) of genomic DNA from several isolates each of $F$. avenaceum, $F$. coeruleum, $F$. culmorum, and F. sulphureum using the PCR-ELISA format. The detection limits for seeded peel extracts $(0.5 \mathrm{ml})$ for each PCR-ELISA assay were set at 12.5 macroconidia for $F$. coeruleum and $F$. avenaceum and 25 macroconidia for $F$. sulphureum and $F$. culmorum. The optimal concentration of competitor fragment for inclusion with Fusarium spp. target DNA per reaction for quantitative PCR was determined to be $10,50,20$, and 5 ag for $F$. avenaceum, F. coeruleum, F. culmorum, and $F$. sulphureum, respectively.

Real-time (TaqMan) PCR assays designed to detect $F$. avenaceum, F. coeruleum, F. culmorum, and F. sulphureum were tested over various concentrations of primers and probes. Optimal primer concentrations ranged from 100 to 300 or $900 \mathrm{nM}$, with a probe concentration set at $100 \mathrm{nM}$ for each assay (Table 1). The 
optimized assay for the specific detection of $F$. sulphureum also used a degenerate forward primer with the inclusion of two reverse primers for an increased specificity and sensitivity (Table 1). The specificity of all TaqMan assays was confirmed by testing DNA from the wide range of fungal pathogens available (Table 2), and the results were in agreement with the corresponding conventional PCR assay. Each TaqMan assay could reliably detect attogram $\left(10^{-18} \mathrm{~g}\right)$ levels of genomic DNA extracted from $\mathrm{Fu}$ sarium spp. The standard curves produced for each specific assay for real-time PCR and PCR-ELISA showed high correlation coefficient $\left(R^{2}\right)$ values $(0.96$ to 0.99$)$, indicating a reproducible linear response in detection related to increasing conidial concentration. The efficiency of each real-time PCR standard curve was determined using the formula, $10^{[-1 / \text { slope }]}-1$ (Applied Biosystems), and levels of $95,96,91$, and $94 \%$ were calculated for the assays for $F$. avenaceum, F. coeruleum, F. culmorum, and F. sulphureum, respectively.

Monitoring tuber stocks for presence of Fusarium spp. Real-time PCR testing of tuber samples revealed that all four potato seed stocks sampled from commercial stores were contaminated with $F$. avenaceum, $F$. sulphureum, F. culmorum, and $F$. coeruleum, either singly or in combination, on at least one sampling date (Table 3). F. avenaceum and F. sulphureum were detected in all four stocks (A, C, F, and G), F. culmorum was detected in three stocks $(\mathrm{C}, \mathrm{F}$, and $\mathrm{G})$, and $F$. coeruleum was detected in all four stocks only at sampling date 4 . There was no significant difference in the level of contamination of boxes for any Fusarium pathogen between dates 1 and 2 (Table 3). However, the mean DNA level of Fusarium spp. detected was higher in the second generation of seed in some stocks sampled at dates 3 or 4 . For example, levels were significantly higher $\left(10^{4}\right.$ - to $10^{5}$ fold; $P<0.05$ ) for $F$. avenaceum (stocks A, C, F, and $\mathrm{G}$, date 3), F. culmorum (stock C, date 3 ), and F. sulphureum (stock C, date 4); F. sulphureum was detected in all four stocks at levels comparable to those at date 1 , except that significantly higher levels were detected in stock $C(P<0.05)$ at date 4 . Significantly lower levels of $F$. avenaceum $\left(10^{3}\right.$-fold; $\left.P<0.05\right)$ were detected in two of the four stocks ( $\mathrm{C}$ and $\mathrm{F}$, date 4$)$, and F. culmorum was not detected in any of the stocks sampled at date 4. However, at this date, $F$. coeruleum was detected for the first time at comparable levels in all four stocks down to fg levels (0.04 to 4.0) (Table 3). The data indicated that there was a general trend of increased Fusarium spp. contamination in the second generation of seed sampled from commercial seed stocks. Overall, there were no significant differences in mean target DNA levels between stocks for each species. A comparison of the data represented as mean number of conidia per milliliter detected in tuber extracts for each Fusarium spp. in stocks $\mathrm{C}$ and $\mathrm{F}$ (second generation seed) by real-time PCR and PCR-ELISA revealed no significant differences $(P<0.05)$ (Table 3$)$.

Relationship between tuber contamination by Fusarium spp. and disease development. The amount of DNA detected on tubers immediately following inoculation with different conidial concentrations (time 0) (Table 4) varied significantly between Fusarium spp. (up to $10^{6}$-fold). It would appear that $F$. avenaceum attached poorly to tubers because an extremely low level of target DNA $(0.03 \mathrm{fg})$ was detected at only the highest inoculum concentration $\left(10^{6}\right.$ conidia/ml $)$. In contrast, $F$. culmorum may have been the most efficient species to bind to tubers after inoculation because the highest DNA levels were detected for this isolate at all inoculum levels. Increasing levels of target DNA (near 10fold) related to increasing initial inoculum concentration were detected in postinoculation samples for $F$. culmorum, $F$. coeruleum, and $F$. sulphureum, but not $F$. avenaceum. The amount of $F$. sulphureum and $F$. coeruleum DNA (fg) detected increased significantly $(P<0.05)$ as the incubation period increased from 2 to 12 weeks (Table 4$)$. Significantly $(P<0.05)$ higher disease scores were observed on tubers inoculated with $F$. sulphureum and $F$. coeruleum than with $F$. avenaceum and $F$. culmorum (Table 4). Tubers inoculated with $F$. sulphureum had more disease at the lowest inoculum concentration $\left(10^{4}\right.$ conidia/ml $)$ after 8 and 12 weeks of storage than those inoculated with any other species, whereas $F$. coeruleum produced the highest disease scores at the highest inoculum concentration $\left(10^{6}\right.$ conidia/ml $)$. Disease symptoms also were evident after 2 weeks of storage on tubers inoculated with $F$. coeruleum at high levels $\left(10^{5}\right.$ and $10^{6}$ conidia $\left./ \mathrm{ml}\right)$. In contrast, disease symptoms were detected only after 12 weeks storage on tubers of cvs. Spunta and Morene inoculated with F. culmorum.

Increasing the inoculum concentration had a significant $(P<$ $0.05)$ effect on disease severity when tubers were inoculated with $F$. sulphureum and $F$. coeruleum, and significantly $(P<0.05)$ more disease was recorded as the period of storage increased from 8 to 12 weeks. There also was a significant correlation between high levels of target DNA detected and higher disease scores for both $F$. coeruleum and $F$. sulphureum after 8 and 12 weeks of storage (Table 4). The threshold inoculum levels for significant disease development in cvs. Spunta and Morene compared with the un-inoculated controls was set at $10^{4}$ conidia $/ \mathrm{ml}$ for F. sulphureum and $10^{5}$ conidia/ml for $F$. coeruleum (Table 4).

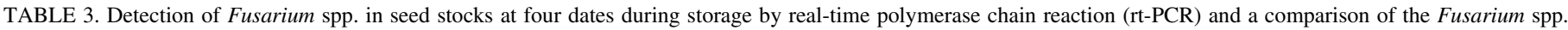
(conidia/ml) detected using rt-PCR and PCR enzyme-linked immunosorbent assay (ELISA)

\begin{tabular}{|c|c|c|c|c|c|c|c|c|c|c|c|c|c|c|c|c|}
\hline \multirow[b]{3}{*}{ Stocks sampled } & \multicolumn{16}{|c|}{ Femtogram $\left(\mathrm{fg} ; 10^{-15} \mathrm{~g}\right)$ levels of target DNA and conidia $/ \mathrm{ml}$ on tubers ${ }^{\mathrm{a}}$} \\
\hline & \multicolumn{4}{|c|}{ F. avenaceum } & \multicolumn{4}{|c|}{ F. culmorum } & \multicolumn{4}{|c|}{ F. sulphureum } & \multicolumn{4}{|c|}{ F. coeruleum } \\
\hline & $\begin{array}{l}\text { Dec } \\
2000\end{array}$ & $\begin{array}{l}\text { Feb } \\
2001\end{array}$ & $\begin{array}{c}\text { Dec } \\
2001\end{array}$ & $\begin{array}{l}\text { Feb } \\
2002\end{array}$ & $\begin{array}{l}\text { Dec } \\
2000\end{array}$ & $\begin{array}{l}\text { Feb } \\
2001\end{array}$ & $\begin{array}{l}\text { Dec } \\
2001\end{array}$ & $\begin{array}{l}\text { Feb } \\
2002\end{array}$ & $\begin{array}{l}\text { Dec } \\
2000\end{array}$ & $\begin{array}{l}\text { Feb } \\
2001\end{array}$ & $\begin{array}{l}\text { Dec } \\
2001\end{array}$ & $\begin{array}{l}\text { Feb } \\
2002\end{array}$ & $\begin{array}{l}\text { Dec } \\
2000\end{array}$ & $\begin{array}{l}\text { Feb } \\
2001\end{array}$ & $\begin{array}{c}\text { Dec } \\
2001\end{array}$ & $\begin{array}{l}\text { Feb } \\
2002\end{array}$ \\
\hline $\begin{array}{l}\text { A. Hermes } \\
\text { rt-PCR (fg DNA) }\end{array}$ & $2.7 \times 10^{-1}$ & $1.5 \times 10^{0}$ & $8.4 \times 10^{4^{*}}$ & 0 & 0 & 0 & 0 & 0 & 0 & $8.0 \times 10^{-3}$ & $2.8 \times 10^{0}$ & $2.8 \times 10^{0}$ & 0 & 0 & 0 & $1.4 \times 10^{-1}$ \\
\hline $\begin{array}{l}\text { G. Spunta } \\
\text { rt-PCR (fg DNA) }\end{array}$ & $6.0 \times 10^{-2}$ & $3.8 \times 10^{-2}$ & $6.0 \times 10^{3^{*}}$ & 0 & $1.1 \times 10^{-1}$ & $5.4 \times 10^{-1}$ & 0 & 0 & 0 & $3.1 \times 10^{-5}$ & $1.3 \times 10^{0}$ & $1.4 \times 10^{0}$ & 0 & 0 & 0 & $4.2 \times 10^{-2}$ \\
\hline C. Morene & & & & & & & & & & & & & & & & \\
\hline rt-PCR (fg DNA) & $4.3 \times 10^{-2}$ & $7.3 \times 10^{-1}$ & $5.6 \times 10^{3^{*}}$ & $1.1 \times 10^{0}$ & $7.9 \times 10^{-2}$ & $4.2 \times 10^{-2}$ & $4.2 \times 10^{-2^{*}}$ & 0 & $6.7 \times 10^{-4}$ & 0 & $2.6 \times 10^{-1}$ & $1.7 \times 10^{1^{*}}$ & 0 & 0 & 0 & $4.5 \times 10^{0}$ \\
\hline rt-PCR (conidia/ml) & $\ldots$ & $\ldots$ & $6.5 \times 10^{6}$ & $1.5 \times 10^{4}$ & $\ldots$ & $\ldots$ & $3.6 \times 10^{4}$ & 0 & $\ldots$ & $\ldots$ & $4.3 \times 10^{2}$ & $3.6 \times 10^{3}$ & $\ldots$ & $\ldots$ & 0 & $2.2 \times 10^{4}$ \\
\hline PCR-ELISA (conidia/ml) & $\ldots$ & $\ldots$ & $4.8 \times 10^{5}$ & $2.1 \times 10^{3}$ & $\ldots$ & $\ldots$ & $7.5 \times 10^{5}$ & 0 & $\ldots$ & $\ldots$ & $6.8 \times 10^{3}$ & $1.1 \times 10^{4}$ & $\ldots$ & $\ldots$ & 0 & $6.6 \times 10^{6}$ \\
\hline F. Spunta & & & & & & & & & & & & & & & & \\
\hline rt-PCR (fg DNA) & $8.4 \times 10^{-1}$ & $4.6 \times 10^{-1}$ & $8.2 \times 10^{3^{*}}$ & $9.8 \times 10^{-1}$ & 0 & $3.4 \times 10^{-3}$ & 0 & 0 & $1.9 \times 10^{-3}$ & $4.0 \times 10^{-4}$ & $1.2 \times 10^{0}$ & $1.4 \times 10^{0}$ & 0 & 0 & 0 & $4.3 \times 10^{-2}$ \\
\hline rt-PCR (conidia/ml) & $\ldots$ & $\ldots$ & $2.6 \times 10^{6}$ & $1.5 \times 10^{4}$ & $\ldots$ & $\ldots$ & 0 & 0 & $\ldots$ & $\ldots$ & $1.8 \times 10^{3}$ & $9.0 \times 10^{2}$ & $\ldots$ & $\ldots$ & 0 & $2.2 \times 10^{4}$ \\
\hline PCR-ELISA (conidia/ml) & $\ldots$ & $\ldots$ & $1.4 \times 10^{6}$ & $1.1 \times 10^{4}$ & $\ldots$ & $\ldots$ & 0 & 0 & $\ldots$ & $\ldots$ & $8.6 \times 10^{3}$ & $4.1 \times 10^{3}$ & $\ldots$ & $\ldots$ & 0 & $1.9 \times 10^{5}$ \\
\hline
\end{tabular}

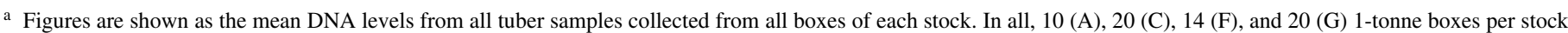
were monitored. Results were determined from mean DNA values per stock for rt-PCR, and corresponding mean target:competitor DNA ratios for PCR-ELISA. Values of conidia/ml were calculated using the linear regression equation for each standard curve per species; $\ldots=$ not determined; $*=$ significant differences $(P<0.05)$ between mean DNA levels were detected for each stock over four sampling periods. 
No significant disease was recorded on tubers inoculated with $F$. avenaceum or $F$. culmorum at any inoculum concentration, and the amount of DNA detected (fg) remained low throughout storage. Low levels of target DNA for $F$. avenaceum and $F$. coeruleum were detected on noninoculated control tubers during storage and, although significantly higher DNA concentrations were detected for $F$. sulphureum, none of these levels resulted in disease even after 12 weeks of incubation. Overall, there was no significant difference in disease severity recorded between the cvs. Spunta and Morene.

Effect of soil contamination and harvest date on disease incidence. Seed samples of cvs. Morene and Spunta used in the field trial were naturally contaminated with low levels (0.6 to $2 \mathrm{fg}$ ) of $F$. avenaceum and $F$. sulphureum (Table 5). A low level of F. avenaceum DNA (0.22 fg) also was detected in one soil plot pre- inoculation, whereas samples from the remaining 17 plots gave negative results when tested for all Fusarium spp. using the realtime PCR assay. Soil samples collected immediately postinoculation of the soil gave a significantly higher number of positive results for all four Fusarium spp. (Table 5).

Only $F$. culmorum and $F$. sulphureum were detected in soil plots at harvest (Table 5), and the number of positive samples was significantly $(P<0.05)$ lower than found immediately post-inoculation (Table 5). There were no significant differences in the mean levels of F. culmorum target DNA detected in soil plots used for growing cv. Spunta at the different harvest dates, whereas the mean DNA levels of $F$. sulphureum detected were significantly $(P<0.05)$ greater at the final harvest $(5$ November 2002) compared with the earliest harvest date (4 September 2002). Target DNA of F. culmorum and F. sulphureum was detected at

TABLE 4. Mean disease scores (0-to-5 scale) from tubers inoculated with varying concentrations of conidia of Fusarium spp. after storage for different times at $12^{\circ} \mathrm{C}$ and $85 \%$ relative humidity and corresponding mean levels of target DNA (femtogram $[\mathrm{fg}] ; 10^{-15} \mathrm{~g}$ ) detected ${ }^{\mathrm{a}}$

\begin{tabular}{|c|c|c|c|c|c|c|c|c|}
\hline \multirow[b]{2}{*}{ Cultivar, time (weeks) } & \multicolumn{2}{|c|}{0 conidia/ml } & \multicolumn{2}{|c|}{$10^{4}$ conidia $/ \mathrm{ml}$} & \multicolumn{2}{|c|}{$10^{5}$ conidia/ml } & \multicolumn{2}{|c|}{$10^{6}$ conidia $/ \mathrm{ml}$} \\
\hline & Score & fg DNA & Score & fg DNA & Score & fg DNA & Score & fg DNA \\
\hline \multicolumn{9}{|l|}{ F. avenaceum } \\
\hline \multicolumn{9}{|l|}{ Spunta } \\
\hline 0 & $\ldots$ & 0 & $\ldots$ & 0 & $\ldots$ & 0 & $\ldots$ & 0.030 \\
\hline 2 & 0 & 0.138 & 0 & 0.634 & 0 & 0.946 & 0 & 2.684 \\
\hline 8 & 0 & 0.096 & 0 & 0.208 & 0.1 & 0.359 & 0 & 0.294 \\
\hline 12 & 0 & 0.318 & 0 & 0.387 & 0.1 & 0.995 & 0.2 & 1.733 \\
\hline$P$ & $\ldots$ & $\ldots$ & $\ldots$ & $\ldots$ & $\ldots$ & $\ldots$ & $\ldots$ & $\ldots$ \\
\hline \multicolumn{9}{|l|}{ Morene } \\
\hline 0 & $\ldots$ & 0 & $\ldots$ & 0 & $\ldots$ & 0 & $\ldots$ & 0.227 \\
\hline 2 & 0 & 0.325 & 0 & 0.220 & 0 & 0 & 0 & 0.419 \\
\hline 8 & 0 & 0.796 & 0 & 0.336 & 0 & 0.342 & 0 & 0.292 \\
\hline 12 & 0 & 0.762 & 0 & 1.060 & 0 & 1.883 & 0 & 1.389 \\
\hline$P$ & $\ldots$ & $\ldots$ & $\ldots$ & $\ldots$ & $\ldots$ & $\ldots$ & $\ldots$ & $\ldots$ \\
\hline \multicolumn{9}{|l|}{ F. coeruleum } \\
\hline \multicolumn{9}{|l|}{ Spunta } \\
\hline 0 & $\ldots$ & 0 & $\ldots$ & 1.274 & $\ldots$ & 19.08 & $\ldots$ & 145.80 \\
\hline 2 & 0 & 0 & 0 & 1.107 & 0.3 & 2.82 & 0.9 & 20.98 \\
\hline 8 & 0 & 0.047 & 0.6 & 131.71 & 1.8 & $2,253.17$ & 2.3 & $4,442.92$ \\
\hline 12 & 0 & 2.960 & 0.3 & $12,275.88$ & 1.9 & $297,101.9$ & 3.2 & $956,634.9$ \\
\hline$P$ & $\ldots$ & $\ldots$ & $\ldots$ & $\ldots$ & $<0.05$ & $<0.05$ & $<0.05$ & $<0.05$ \\
\hline \multicolumn{9}{|l|}{ Morene } \\
\hline 0 & $\ldots$ & 0 & $\ldots$ & 1.70 & $\ldots$ & 17.67 & $\ldots$ & 127.57 \\
\hline 2 & 0 & 0 & 0 & 0.286 & 0.4 & 1.99 & 1.0 & 7.49 \\
\hline 8 & 0 & 0.027 & 0.7 & 402.40 & 1.2 & $2,045.70$ & 2.6 & $7,542.05$ \\
\hline 12 & 0 & 0.340 & 0.3 & 382.75 & 1.2 & $130,301.0$ & 3.1 & $967,711.4$ \\
\hline$P$ & $\ldots$ & $\ldots$ & $\ldots$ & $\ldots$ & $<0.05$ & $<0.05$ & $<0.05$ & $<0.05$ \\
\hline \multicolumn{9}{|l|}{ F. culmorum } \\
\hline \multicolumn{9}{|l|}{ Spunta } \\
\hline 0 & $\ldots$ & 0 & $\ldots$ & 39.78 & $\ldots$ & $3,791.68$ & $\ldots$ & $37,514.65$ \\
\hline 2 & 0 & 0 & 0 & 632.65 & 0 & $2,665.78$ & 0 & $6,681.56$ \\
\hline 8 & 0 & 0 & 0 & 452.53 & 0 & $1,902.67$ & 0 & $2,679.23$ \\
\hline 12 & 0 & 0 & 0 & 749.35 & 0.2 & 648.07 & 0.6 & $2,744.64$ \\
\hline$P$ & $\ldots$ & $\ldots$ & $\ldots$ & $\ldots$ & $\ldots$ & $\ldots$ & $<0.05$ & $\ldots$ \\
\hline \multicolumn{9}{|l|}{ Morene } \\
\hline 0 & $\ldots$ & 0 & $\ldots$ & 32.46 & $\ldots$ & $4,688.59$ & $\ldots$ & $55,527.36$ \\
\hline 2 & 0 & 0 & 0 & 20.67 & 0 & 540.56 & 0 & $2,830.23$ \\
\hline 8 & 0 & 0 & 0 & 68.77 & 0 & 517.37 & 0 & $3,809.39$ \\
\hline 12 & 0 & 0 & 0.2 & 505.37 & 0.3 & $2,086.50$ & 0.4 & $3,745.01$ \\
\hline$P$ & $\ldots$ & $\ldots$ & $\ldots$ & $\ldots$ & $\ldots$ & $\ldots$ & $\ldots$ & $\ldots$ \\
\hline \multicolumn{9}{|l|}{ F. sulphureum } \\
\hline \multicolumn{9}{|l|}{ Spunta } \\
\hline 0 & $\ldots$ & 6.60 & $\ldots$ & 3.20 & $\ldots$ & 14.07 & $\ldots$ & 74.57 \\
\hline 2 & 0 & 0.070 & 0 & 45.80 & 0 & 80.02 & 0 & 113.15 \\
\hline 8 & 0 & 5.94 & 1.5 & $6,710.28$ & 2.2 & $151,946.4$ & 0.7 & $103,562.0$ \\
\hline 12 & 0 & 72.45 & 1.3 & $79,995.55$ & 2.9 & $215,800.7$ & 1.6 & $81,441.84$ \\
\hline$P$ & $\ldots$ & $\ldots$ & $\ldots$ & $\ldots$ & $<0.05$ & $<0.05$ & $\ldots$ & $\ldots$ \\
\hline \multicolumn{9}{|l|}{ Morene } \\
\hline 0 & $\ldots$ & 3.56 & $\ldots$ & 26.26 & $\ldots$ & 16.32 & $\ldots$ & 77.78 \\
\hline 2 & 0 & 35.35 & 0 & 69.15 & 0 & 92.37 & 0 & 159.16 \\
\hline 8 & 0 & $3,565.75$ & 1.2 & $4,861.47$ & 1.9 & $48,788.0$ & 2.6 & $29,515.57$ \\
\hline 12 & 0 & $67,764.51$ & 2.0 & $114,977.6$ & 2.9 & $134,469.1$ & 2.5 & $90,509.91$ \\
\hline$P$ & $\ldots$ & $\ldots$ & $<0.05$ & $\ldots$ & $<0.05$ & $\ldots$ & $<0.05$ & $\ldots$ \\
\hline
\end{tabular}

${ }^{a}$ Disease score: $0=$ no infection, $1=0$ to $12.5,2=12.5$ to $25,3=25$ to $50,4=50$ to 75 , and $5=>75 \%$. 
only one harvest date each in soil used for planting Morene on 17 September and 5 November 2002, respectively (Table 5). $F$. avenaceum and $F$. coeruleum were not detected in any of the 72 soil DNA extracts at all three harvest dates.

Overall, lower levels of target DNA of $F$. avenaceum, $F$. culmorum, and $F$. sulphureum were detected in the daughter tubers of Morene compared with Spunta at the majority of harvest dates, although these were not significant at the 5\% level (Table 5). F. coeruleum was detected only in Spunta tubers harvested on 5 November 2002 (Table 5). There was no significant difference in the amount of $F$. avenaceum DNA detected on progeny tubers of either cultivar at the different harvest dates (Table 5). In the case of $F$. culmorum, higher levels of target DNA were detected at the first harvest date (4 September 2002) for both Spunta (1,000 fg) and Morene (21 fg) (Table 5) and, although the levels decreased during the subsequent harvest dates, DNA levels were significantly $(P<0.05)$ higher only at this date in the former cultivar. This is in contrast to the findings for $F$. sulphureum, because higher DNA levels were detected at the final harvest date $(5 \mathrm{No}-$ vember 2002) for both Spunta and Morene, and these levels were significant $(P<0.05)$ for the latter cultivar (Table 5).

\section{DISCUSSION}

The objective of this research was to use robust diagnostic assays for epidemiological studies of the dry-rot-causing $\mathrm{Fu}$ sarium spp. Two types of quantitative molecular diagnostic assay were developed: real-time PCR based on TaqMan chemistry and PCR-ELISA. The use of these PCR assays to detect the four main Fusarium storage rot pathogens ( $F$. avenaceum, F. sulphureum, F. culmorum, and F. coeruleum) prevalent in the United Kingdom was demonstrated. Both assays were of a high sensitivity and specificity and allowed the detection of Fusarium spp. on potato tubers. The reliability of the diagnostic assays was rigorously tested with over 500 fungal pathogen isolates, including those from potato and reference culture collections, and both real-time and PCR ELISA methods produced similar results. In terms of sensitivity, the detection limits for real-time PCR went below attogram DNA levels, whereas the limit for PCR-ELISA assays was fg levels of DNA.
There was no significant difference $(P<0.05)$ between diagnostic methods for the detection of Fusarium spp. levels in commercial potato seed stocks (Table 3), demonstrating that methods were comparable in terms of pathogen detection and that the tuber peel DNA extraction procedure and detection assays were of the required quality and sensitivity for monitoring potato stocks for fungal pathogens. Real-time PCR has the advantage of calculating the absolute quantity of pathogen DNA in tuber or soil samples within $2.5 \mathrm{~h}$, in contrast to the $6.5 \mathrm{~h}$ taken by the PCR-ELISA method, which has the disadvantage of including additional steps (DIG detection) during the quantification of PCR products.

Real-time PCR assays incorporated primers to detect the COX gene for use as a potato endogenous control during quantification (39). The COX gene assay was used to normalize all the quantitative values for the target (Fusarium spp. DNA) by amount of potato DNA present in the extract and, hence, the level of target per amount of potato tissue sampled. This normalization process takes into account differences in the amount of tissue sampled, the quantity of DNA extracted from each sample, and also any variance in the volumes of reagents and DNA aliquoted into each PCR reaction. A normalizer assay could be incorporated into the PCR-ELISA format but would require the design of an additional capture probe for the COX gene PCR product plus an additional competitor standard for quantification. These steps would further increase the complexity and duration of the PCR ELISA assay. However, the choice between the two PCR systems will be dictated by the cost of equipment, reagents, and staff time as well as the level of throughput required. Real-time PCR equipment, although now available from a range of suppliers, is still more expensive than the equipment required for PCR-ELISA, whereas the reagent costs of the PCR-ELISA are higher per assay than for real-time PCR. The hands-on time required to reach a result for PCR-ELISA is higher than for real-time PCR and, therefore, it is easier to achieve a greater throughput of samples using real-time PCR than it is with PCR-ELISA.

The assays adapted to PCR-ELISA applications were designed to operate under standard conditions at both the PCR stage and DIG detection and quantification of target DNA (Materials and Methods). Other diagnostic assays developed in our laboratory for the detection of potato pathogens, including Colletotrichum coc-

TABLE 5. Mean levels of Fusarium spp. DNA (femtogram [fg]) detected in disease-free seed tubers and inoculated soil plots before planting crop and in soil and progeny tubers at different harvest dates

\begin{tabular}{|c|c|c|c|c|c|}
\hline \multirow[b]{2}{*}{ Cultivar, soil } & \multirow[b]{2}{*}{ Harvest date } & \multicolumn{4}{|c|}{ Mean DNA levels (fg) of Fusarium spp. detected in tuber and soil samples ${ }^{\mathrm{a}}$} \\
\hline & & F. avenaceum & F. coeruleum & F. culmorum & F. sulphureum \\
\hline \multicolumn{6}{|l|}{ Pre-planting } \\
\hline Soil pre-inoculation ${ }^{\mathrm{b}}$ & $\ldots$ & $0.22(1 / 36)$ & 0 & 0 & 0 \\
\hline Soil post-inoculation soil ${ }^{b}$ & $\ldots$ & $0.42(20 / 36)$ & $0.43(26 / 36)$ & $117(27 / 36)$ & $38.5(30 / 36)$ \\
\hline Spunta G0 seed ${ }^{\mathrm{c}}$ & $\ldots$ & $2.14(4 / 8)$ & 0 & 0 & $0.776(6 / 8)$ \\
\hline Morene G0 seed ${ }^{c}$ & $\ldots$ & $1.54(2 / 8)$ & 0 & 0 & $0.697(5 / 8)$ \\
\hline \multicolumn{6}{|l|}{ Harvest } \\
\hline \multirow[t]{3}{*}{ Soil after Spunta growth ${ }^{\mathrm{d}}$} & 4 September 2002 & 0 & 0 & 14.79 & $7.10 \times 10^{-3}$ \\
\hline & 17 September 2002 & 0 & 0 & 4.29 & 0 \\
\hline & 5 November 2002 & 0 & 0 & 9.59 & $2.72^{*}$ \\
\hline \multirow[t]{3}{*}{ Soil after Morene growth ${ }^{\mathrm{d}}$} & 4 September 2002 & 0 & 0 & 0 & 0 \\
\hline & 17 September 2002 & 0 & 0 & 703.2 & 0 \\
\hline & 5 November 2002 & 0 & 0 & 0 & 0.128 \\
\hline \multirow[t]{3}{*}{ Spunta progeny } & 4 September 2002 & $4.10 \times 10^{-3}$ & 0 & $1.51 \times 10^{3^{*}}$ & 0.102 \\
\hline & 17 September 2002 & $2.02 \times 10^{-3}$ & 0 & $4.35 \times 10^{2}$ & 1.19 \\
\hline & 5 November 2002 & $1.12 \times 10^{-3}$ & 0.196 & 0.69 & 15.11 \\
\hline \multirow{3}{*}{ Morene progeny } & 4 September 2002 & $1.28 \times 10^{-2}$ & 0 & 21.9 & $8.42 \times 10^{-2}$ \\
\hline & 17 September 2002 & $5.08 \times 10^{-4}$ & 0 & 3.49 & $1.19 \times 10^{-2}$ \\
\hline & 5 November 2002 & $6.05 \times 10^{-4}$ & 0 & 2.37 & $2.18^{*}$ \\
\hline
\end{tabular}

a Asterisk $(*)$ indicates significant differences $(P<0.05)$ between mean DNA levels at harvest dates.

b Soil DNA was extracted in duplicate from each of two replicate samples from 18 plots pre- and postinoculation of soil, before planting seed.

${ }^{c}$ Mean DNA levels and number of positive samples detected from a combined peel extract from five tubers per sample tested.

d DNA was extracted from duplicate sub-samples from each of two replicate soil samples per plot.

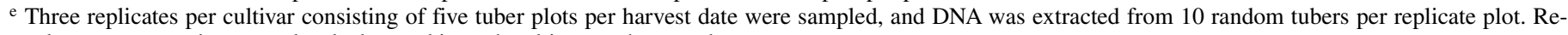
sults are expressed as mean levels detected in each cultivar per harvest date. 
codes (12), Helminthosporium solani (11), Rhizoctonia solani (20), and Spongospora subterranea (36), were designed to operate under the same PCR conditions and could be adapted to a PCR-ELISA format to allow multiple testing of potato stocks. Bailey et al. (2) also developed PCR-ELISA assays using unique sequences of the ITS1 regions as capture probes for the identification of several Phytophthora and Pythium spp. This is the first report of the use of the quantitative PCR-ELISA format for monitoring potato pathogens. However, due to the speed, higher sensitivity, and normalization of data with real-time PCR, this technique was used as the main tool in the reported epidemiological investigations.

Hide et al. (16) reported that $F$. avenaceum, $F$. coeruleum, $F$. culmorum, and $F$. sulphureum were the prevalent dry-rotcausing Fusarium spp. in the United Kingdom in 1992. In addition, Peters et al. (24) reported the same four species predominated during a survey (2000 to 2002) of the regional variation in Fusarium spp. throughout England and Scotland. These findings also were supported by the observations of UK potato growers; therefore, it was important to provide diagnostics to detect all four species for epidemiological investigations of commercial potato seed stocks. All four Fusarium spp. subsequently were detected in four potato stocks (three cultivars) sampled from Scottish stores over two generations of seed (Table 3 ). There was a significant increase in Fusarium spp. contamination in the second generation of seed sampled from some stocks, suggesting that either there was multiplication of the Fusarium spp. on the tuber surface over time or additional contamination through the handling and replanting process was occurring. The source of this contamination, either infested soil or contaminated seed tubers, is not clear; however, there is a predilection for both sources. Seed grown in soils highly contaminated with Fusarium spp. was responsible for contamination of seed stocks in Maine and New Brunswick in North America (23), whereas seedborne inoculum also was shown to be responsible for daughter tuber contamination from plants produced from $F$. sulphureum contaminated seed (18). Tubers sampled from boxes from the four stocks showed a disease incidence of between 1.2 and $6.2 \%(n=20$ tubers) when monitored over two seed generations, demonstrating that the levels of $\mathrm{Fu}$ sarium spp. contamination detected can result in disease symptom expression (D. W. Cullen, unpublished data).

$F$. sulphureum and $F$. coeruleum produced significantly $(P<$ 0.05 ) more disease on tubers than $F$. avenaceum and $F$. culmorum. These observations may be a reflection of differences in the ability of each species to attach to the tuber surface and initiate growth under the given storage conditions. In addition, $F$. sulphureum caused significantly more disease than the other species at the lowest inoculum level $\left(10^{4}\right.$ conidia $\left./ \mathrm{ml}\right)$, whereas $F$. coeruleum produced the most disease at the highest inoculum level $\left(10^{6}\right.$ conidia $\left./ \mathrm{ml}\right)$, further highlighting differences in the biology between the species.

This study focused on relatively high inoculum levels, because a previous experiment had shown that inoculum levels of $10^{4}$ to $10^{6} \mathrm{conidia} / \mathrm{ml}$ were required for significant disease to develop during storage (D. W. Cullen, unpublished data). The threshold inoculum levels for significant disease to develop on cvs. Spunta and Morene were set at $10^{4}$ conidia/ml for $F$. sulphureum and $10^{5}$ conidia/ml for $F$. coeruleum. Based on a DNA equivalence, it can be speculated that levels of F. sulphureum and F. coeruleum DNA ranging between 10 and 100 fg per tuber detected prestorage has the potential to cause disease and, at levels 1,000-fold greater than this (10 to $100 \mathrm{pg}$ per tuber), disease development is likely to be imminent or present. Thus, a scale from $10 \mathrm{fg}$ (disease possible under ideal conditions) to $100 \mathrm{pg}$ (disease present or imminent) of DNA per tuber would seem a reasonable scale to begin relating diagnostic results to disease scores in commercial stocks. The low disease levels caused by $F$. avenaceum and F. culmorum may be related to the storage conditions used and differences in the susceptibility of the potato cultivars to rotting by such species, because an increase in aggressiveness of F. avenaceum was reported at lower temperatures $\left(5^{\circ} \mathrm{C}\right)$ and this was influenced by cultivar (26).

The low number of soil samples containing any Fusarium spp. at different harvest dates suggested that these species do not exist in high concentrations in soil throughout the growing season even after inoculation of the soil at high levels $\left(10^{5}\right.$ and $10^{6}$ conidia $\left./ \mathrm{ml}\right)$ before planting of the potato crop. Only F. sulphureum and F. culmorum were detected in soil plots at harvest, suggesting that the conidia of $F$. avenaceum and $F$. coeruleum either had not survived during the season or were below the detection limits by dilution through the soil. This is in contrast to a survey of potato soils in Maine in the United States, which reported that F. coeruleum was most often isolated, whereas $F$. sulphureum was not recovered from any soil (18). Factors that could affect the soil populations of Fusarium spp. will include potato cultivars, rotation crops, suppressive soils, and soil structure or type. However, cropping practices appeared to have little influence on Fusarium spp. content in Maine potato soils and resulting dry rot levels in storage; however, soil suppressiveness of fungal pathogenicity was reported to be responsible for a low incidence of the disease (18).

In contrast to the pathogen levels in soils, $F$. avenaceum, F. culmorum, and F. sulphureum were detected on the daughter tubers of Morene and Spunta at all harvest dates, whereas F. coeruleum was only detected on Spunta tubers at the final harvest (Table 5). There was a general trend of higher contamination levels of $F$. culmorum detected in progeny tubers at the earliest harvest date in contrast to higher DNA levels of $F$. sulphureum at the final harvest date. In the case of $F$. sulphureum, the higher levels of contamination on daughter tubers also was correlated with the highest levels of DNA detected in soil at the final harvest date. Such differences in disease incidence caused by the different species may be related to their ability to sporulate. F. coeruleum sporulates on the outside of rotting seed tubers, whereas $F$. sulphureum rarely does so, but rather sporulates on stem bases (1). Both these sources of inoculum may result in soil infestation around progeny tubers. Choiseul et al. (10) demonstrated that inoculating stem bases with $F$. sulphureum resulted in greater soil populations at harvest and more dry rot on tubers than inoculating the seed tuber, and high soil populations of $F$. coeruleum were detected only when rotting seed tubers were planted, in contrast to sowing contaminated seed (33). Because only F. sulphureum and F. culmorum were detected in soil plots at harvest, transmission of $F$. culmorum to progeny tubers may be greater from stem inoculum than from contaminated seed, as reported for F. sulphureum, whereas inoculum of $F$. avenaceum may be more readily transmitted from rotting than contaminated seed tubers, as was associated with $F$. coeruleum (1). Additional experiments clearly are required to draw firm conclusions about such species differences with regard to inoculum sources, cultivar differences, and harvesting dates.

Considerable new knowledge has been gained in this study about the dry rot complex of pathogens for which little epidemiological information was previously available. The development of reliable and sensitive diagnostics for the dry rot pathogens in this study and the initial findings on the epidemiology of such $F u$ sarium spp. will direct further studies to determine the precise nature of some of the associations discussed. Together with the DNA extraction protocols, these diagnostic methods will allow a rapid and accurate assessment of variables such as storage conditions (temperature and atmospheric conditions in boxes), cultivar susceptibility to different Fusarium spp., soil factors, crop rotations, and climate on the incidence and severity of dry rot disease. Conclusive findings will be possible only through the accumulation of data resulting from the extensive application of these assays by the potato industry. This study has highlighted the importance of Fusarium spp. identification for disease prediction, 
and has shown that determining the levels of seed contamination, soil infestation, and progeny tuber contamination postharvest will assist in management decisions to reduce the disease.

\section{ACKNOWLEDGMENTS}

This work was funded by the Department for Environment, Food and Rural Affairs (DEFRA), Higgins Agriculture Ltd., The British Potato Council, and The Scottish Executive Environment and Rural Affairs Department (SEERAD) through the Sustainable Arable Link Programme (grant number LK0910). We thank L. Allen (SASA) and S. Foster (Rothamsted Research) for the generous provision of isolates; and J. Stewart, E. Warden, and L. Sullivan (SCRI) for assistance with peel sap extractions and peel and soil DNA extractions.

\section{LITERATURE CITED}

1. Adams, M. J., and Lapwood, D. H. 1983. Transmission of Fusarium solani var. coeruleum and $F$. sulphureum from seed potatoes to progeny tubers in the field. Ann. Appl. Biol. 103:411-417.

2. Bailey, A. M., Mitchell, D. J., Manjunath, K. L., Nolasco, G., and Niblett, C. L. 2002. Identification to the species level of the plant pathogens Phytophthora and Pythium by using unique sequences of the ITS1 region of ribosomal DNA as capture probes for PCR ELISA. FEMS Microbiol. Lett. 207:153-158.

3. Beck, E., Ludwig, G., Auerswald, E. A., Reiss, B., and Schaller, H. 1982. Nucleotide sequence and exact location of the neomycin phosphotransferase gene from transposon Tn5. Gene 19:327-336.

4. Boyd, A. E. W. 1972. Potato storage diseases. Rev. Plant Pathol. 51:279321.

5. Bradshaw, N. J., Turner, J. A., and Elcock, S. J. 2001. Potatoes: A survey of diseases 2000/01. Ministry of Agriculture, Fisheries and Food Report.

6. Carnegie S. F., Cameron, A. M., and Haddon, P. 2001. The effect of date of haulm destruction and harvest on the development of dry rot caused by Fusarium solani var. coeruleum on potato tubers. Ann. Appl. Biol. 139:209-216.

7. Carnegie, S. F., Cameron, A. M., Lindsay, D. A., Sharp, E., and Nevison, I. M. 1998. The effect of treating seed potato tubers with benzimidazole, imidazole and phenylpyrrole fungicides on the control of rot and skin blemish diseases. Ann. Appl. Biol. 133:343-363.

8. Carnegie, S. F., Ruthven, A. D., Lindsay, D. A., and Hall, T. D. 1990. Effects of fungicides applied to seed potato tubers at harvest or after grading on fungal storage diseases and plant development. Ann. Appl. Biol. 116:61-72.

9. Chelkowski, J. 1989. Toxigenicity of Fusarium species causing dry rot of potato tubers. Pages 435-440 in: Fusarium Mycotoxins, Taxonomy and Pathogenicity. J. Chelkowski, ed. Elsevier Science Publishing Co., Inc., New York.

10. Choiseul, J. W., Allen, L., and Carnegie, S. F. 2001. The role of stem inoculum in the transmission of Fusarium sulphureum to potato tubers. Potato Res. 44:165-172.

11. Cullen, D. W., Lees, A. K., Toth, I. K., and Duncan, J. M. 2001. Conventional PCR and real-time quantitative PCR detection of Helminthosporium solani in soil and on potato tubers. Eur. J. Plant Pathol. 107:387398.

12. Cullen, D. W., Lees, A. K., Toth, I. K., and Duncan, J. M. 2002. Detection of Colletotrichum coccodes from soil and potato tubers by conventional PCR and real-time quantitative PCR. Plant Pathol. 51:281-292.

13. Desjardins, A. E., Christ-Harned, E. A., McCormick, S. P., and Secor, G. A. 1993. Population structure and genetic analysis of field resistance to thiabendazole in Gibberella pulicaris from potato tubers. Phytopathology 83:164-170.

14. Hanna, K., and Jerzy, C. 1989. Occurrence of Fusarium crookwellense in Poland. Acta Mycol. 24:173-177.

15. Hanson, L. E., Schwager, S. J., and Loria, R. 1996. Sensitivity to thiabendazole in Fusarium species associated with dry rot of potato. Phytopathology 86:378-384.

16. Hide, G. A., Read, P. J., and Hall, S. M. 1992. Resistance to thiabendazole in Fusarium species isolated from potato tubers affected by dry rot. Plant Pathol. 41:745-748.

17. Higgins, D. G., Bleasby, A. J., and Fuchs, R. 1992. ClustalV-Improved software for multiple sequence alignment. Comput. Appl. Biosci. 8:189-191.
18. Leach, S. S. 1985. Contamination of soil and transmission of seedborne potato dry rot fungi (Fusarium spp.) to progeny tubers. Am. Potato J. 62:129-136.

19. Leach, S. S., and Webb, R. E. 1981. Resistance of selected potato cultivars and clones to Fusarium dry rot. Phytopathology 71:623-629.

20. Lees, A. K., Cullen, D. W., Nicolson, M. J., and Hilton, A. J. 2002. Development of a PCR assay for the detection and identification of Rhizoctonia solani AG-3 in potato and soil. Plant Pathol. 51:293-302.

21. Mecteau, M. R., Arul, J., and Tweddell, R. J. 2002. Effect of organic and inorganic salts on the growth and development of Fusarium sambucinum, a causal agent of potato dry rot. Mycol. Res. 106:688-696.

22. Nicholson, P., Simpson, D. R., Weston, G., Rezanoor, H. N., Lees, A. K., Parry, D. W., and Joyce, D. 1998. Detection and quantification of Fusarium culmorum and Fusarium graminearum in cereals using PCR assays. Physiol. Mol. Plant Pathol. 53:17-37.

23. Nielsen, L. W., and Johnson, J. T. 1972. Seed potato contamination with fusarial propagules and their removal by washing. Am. Potato J. 49:391396.

24. Peters, J. C., Stroud, G. S., Lees, A., Cullen, D. W., and Sullivan, L. 2004. Results from a survey of Fusarium spp. on GB potatoes. In: Abstracts of the European Association of Potato Research, Pathology Section Meeting. S. Duvauchelle, ed. Lille, France.

25. Ranganna, B., Kushalappa, A. C., and Raghavan, G. S. V. 1997. Ultraviolet irradiance to control dry rot and soft rot of potato in storage. Can. J. Plant Pathol. 19:30-35.

26. Satyaprasad, K., Bateman, G. L., and Read, P. J. 1997. Variation in pathogenicity on potato tubers and sensitivity to thiabendazole of the dry rot fungus Fusarium avenaceum. Potato Res. 40:357-365.

27. Schisler, D. A., Slininger, P. J., Kleinkopf, G., Bothast, R. J., and Ostrowski, R. C. 2000. Biological control of Fusarium dry rot of potato tubers under commercial storage conditions. Am. J. Potato Res. 77:29-40.

28. Secor, G. A., and Gudmestad, N. C. 1999. Managing fungal diseases of potato. Can. J. Plant Pathol. 21:213-221.

29. Seppanen, E. 1981. Fusariums of the potato in Finland. I. On the $F u$ sarium species causing dry rot in potatoes. Ann. Agric. Fenn. 20:156-160.

30. Singh, B. P., Nagaich, B. B., and Saxena, S. K. 1987. Fungi associated with dry-rot of potatoes, their frequency and distribution. Indian J. Plant Pathol. 5:142-145

31. Stevenson, W. R., Loria, R., Franc, G. D., and Weingartner, D. P. 2001. Compendium of Potato Diseases. 2nd ed. The American Phytopathological Society, St. Paul, MN

32. Theron, D. J., and Holz, G. 1989. Fusarium species associated with dry rot and stem-end rot of potatoes in South Africa. Phytophylactica 21:175181.

33. Tickle, J. H. 1974. Aspects of soil contamination with Fusarium solani var. coeruleum and certain pathogens of potato tubers. Ph.D. thesis, University of Edinburgh.

34. Tivoli, B., Deltour, A., Molet, D., Bedin, P., and Jouan, B. 1986. Mise en évidence de souches de Fusarium roseum var. sambucinum résistantes au thiabendazole, isolées a partir de tubercules de pomme de terre. Agronomie 6:219-224.

35. Turner, A. S., Lees, A. K., Rezanoor, H. N., and Nicholson, P. 1998. Refinement of PCR-detection of Fusarium avenaceum and evidence from DNA marker studies for phenetic relatedness to Fusarium tricinctum. Plant Pathol. 47:278-288.

36. Van de Graaf, P., Lees, A. K., Cullen, D. W., and Duncan J. M. 2003. Detection and quantification of Spongospora subterranea f. sp. subterranea in soil, water and plant tissue samples using real-time PCR. Eur. J. Plant Pathol. 109:589-597.

37. Vaughn, S. F., and Spencer, G. F. 1994. Antifungal activity of natural compounds against thiabendazole-resistant Fusarium sambicinum strains. J. Agric. Food Chem. 42:200-203.

38. Wastie, R. L., Stewart, H. E., and Brown, J. 1989. Comparative susceptibility of some potato cultivars to dry rot caused by Fusarium sulphureum and $F$. solani var. coeruleum. Potato Res. 32:49-55.

39. Wellar, S. A., Elphinstone, J. G., Smith, N. C., Boonham, N., and Stead, D. E. 2000. Detection of Ralstonia solanacearum strains with a quantitative, multiplex, real-time, fluorogenic PCR (TaqMan) assay. Appl. Environ. Microbiol. 66:2853-2858.

40. White, T. J., Bruns, T., Lee, S., and Taylor, J. 1990. Amplification and direct sequencing of fungal ribosomal RNA genes for phylogenetics. Pages 315-322 in: PCR Protocols: A Guide to Methods and Applications. M. A. Innis, D. H. Gelfand, J. J. Sninsky, and T. J. White, eds. Academic Press, San Diego, CA. 